\title{
An Analysis of Ecocriticism in Modern Indian Writing in English With Reference to Priya Kumar'S the Calling
}

\author{
Nirmal Sharma and Shalini Sharma \\ Department of English, SRM Institute of Science and Technology \\ NCR Campus, Modinagar, Ghaziabad, U.P. India
}

\section{ABSTRACT}

Ecocritism is a new approach in the literature which exuberantly focused on interconnected bond among living and non living organisms. Nature and Literature go side by side. Natural scenes provide liveliness to literature. It can inspire, heal and bless anyone if we go through the literature of any time and of anywhere. We can admit this fact thatconcept of mega living and sublimity can be experienced better in the lap of nature. As much as we detach ourselves from nature, we become more selfish and materialistic. The Concept of Self can be understood better in presence of natureas it is perceived in Indian philosophy also. Nature is the best teacher;companion and guide for the seeker. The concept of ecocriticism depicts this relationship between human beings and the environment in all perspective. As far as modern Indian writing is concerned, there is the representation ofmultitudinous. From the very beginning up to now, nature always play an important role in literature.The present paper portraits very beautifully the concept of eco criticism inmodern Indian writing where distorted soul suddenly transform into radiant youth accompany with nature.

\section{KEY WORDS: ECOCRITICISM, DISTRESS, JOURNEY, ENLIGHTENED,}

\section{INTRODUCTION}

During the last three decades, ecocriticism has flourished as 'a worldwide evolving movement'.Thisword ecocriticism was used firstly by William Rueckert in his critical writing "Literature and Ecology: An Experiment in Ecocriticism" in 1978. Etymologically, this word 'eco' comes from the Greek root word 'oikos' meaning earth or household and 'logy' from 'logos' meaning logical discourse.It means logical discourse about environment. In Rueckert points of view, eco criticism relates ecology or its principles into the study of literature. Lawrence Buell also defines ecocriticism "as a study of the relationship between literature and the environment conducted in a spirit of commitment to environmental ist 'spraxis"(The Environmental Imagination, 430).According to the ecocritics nature study is not only the objective of ecocriticism but also search the inseparable bond between human and non human entities on its deeper level.

Biosc Biotech Res Comm P-ISSN: 0974-6455 E-ISSN: 2321-4007
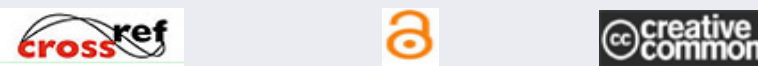

Identifiers and Pagination

Article Information

Year: 2021 Vol: 14 No (8) Special Issue

Received: $10^{\text {th }}$ June 2021

Pages: $211-213$ Accepted after revision: $29^{\text {th }}$ July 2021

This is an open access article under Creative

Commons License Attribn 4.0 Intl (CC-BY).

DOI: $h t t p: / / d x$.doi.org/10.21786/bbrc/14.8.49
As discussed by Joseph Wood Krutch, Thoreau 'swork is not about plants or animals or birds; it is about his relation to them; one may almost say about 'himself in connectionwith nature.'(Henry David Thoreau 1948) Patrick D. Murphy is also right in saying that Ecocriticism is literary "criticism that arises from and is oriented toward a concern with human and non human interaction and interrelationship."

Literature Review: Ecocritics dealt with the term 'nature' in broader sense. It does not only the visualization of its natural objects as plants and animals. It focused on the whole human and non human entities and their interconnectivities. This interconnected bond is the basis of Eco criticism. The harmonic relationship between living and non-living would create healthy eco-system resulting betteroutcome for mankind as well as earth. "The modern ecological consciousness has a feeling that the balancebetween human and the natural world must be maintained. A perfect ecology is one in which plants, animals, birds and human beings live in such harmony that none dominates or destroys the other" (Frederick147). Thus Ecocriticism is an eco friendly approach to literary studies which supports introspection towards our environment.

Priya Kumar portraits appreciably the interconnected bond between environment and human beings in her fictional writings. She symbolizes nature as a teacher and

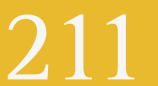


a healer which works on the Law of Abundance. It will provide the things in abundance as per demand."Nature gives you abundance in return for every seed you sow" (115). The writer proves that natural disaster takes place in current scenario due to ignorance of natural resources. If anyone comes in contact of nature consciously, definitely they can get solution of every problem and power back up to face the challenges of life. As said by $\mathrm{R}$ .K. Sharma in his book, The Monk Who Sold His Ferrari: "Every event in our life has a purpose and every setback its lesson. Failure whether of the personal professional or even spiritual kind, is essential to personal expansion. It brings inner growth and a whole host of psychic rewards. Never regret your past. Rather, embrace it as the teacher that it is."(16)

Thematic Analysis: The Calling is a spiritual journey of the protagonist Arjuninto the heart of the Himalayas. Hecomes across with the truth. The liveliness and energetic force that he feels in natural surrounding is remarkable and natural, is the best part of this book. Due to imbalanced and over burden life style,his personal life is at the edge of a divorce. He is totally confused and distorted how to handle the mess up of his life. Suddenly, heencounters a saint (sadhu), who provides him a solution to solve his personal problems by taking journey to HemkundSahib tountie the purple thread which would support him to come out from his personal life problems and would provide purpose in his life which would change his life forever.

Arjun is not aware that it is not the destination (the purple thread), but the journey and the experiences that it is going to change his life forever, and that is what is going to make his soul grow. At every step, natural surrounding and range of mountains which hold secrets and tests that insist on Arjun to evolve into the person that he has denied to be himself. All the negativities like pretenses, falsities, confusions, untruths and distress dropdown which he had created in his life.An experience that leads him to find himself. This journey proves as an opportunityfor selfintrospection of the protagonist. This could be taken as an opportunity to get rid from the withdrawingdistortion of self -created miser. Accompanied by an enlightened 18 years old Chandu, who actually acts as a transporter and, whom Arjun finds irritating more than half of his journey, and realizes at the end that how greater, evolved and ignited soul he is, serving a truly divine purpose. Sometime it feels in the book that Priya Kumar humanizes Himalayas as Chandu who believes in natural therapy and his words and deed in book has divinity. He represents spiritual side of nature that helpsArjun to heal his mess which unconsciously he has created in his own life himself.

Arjunstarts his journey as a confused,over burdened person among the range of Himalayas with Chandu. He is thinking that something magical will happen in his life or he will get some extra ordinary power to make his life happy when he unravels the purple thread in Hemkund Sahib. That is why; he is impatient to reach there. He wants to cross his way as fast as he can but life is long journey as said by Chandu "It takes long, sahib". We have to struggle to achieve good and desired result. The most important part of the book is three tests challenge given to him by the saint which seems simple but having practical examples, and hidden meanings. Arjun has to clear three tests in his journey not only to realize the mistakes he has committed in his life and suggests him the right approach to handle the challenges of life, but also makes his soul to grow and makes him to find his purpose in life.

In the first test, he was encircled with his horse and Chandu. He is being asked to remain in this circle till sadhu returns. After leaving the saint, Arjun feels stink of dead deer which makes the circle polluted and intolerable but anyhow he passes his time till the saint returns. He is not able to clear this first test. According to sadhu "To sit in your space and your world and do nothing in it is a disgrace to the intelligence that you are bestowed with. It is a disgrace to the spiritual force that is inherent to you. Your role in the world is to take charge, to take responsibility for your role in your environment and of what happens in it."

"Your space is your world. There is a larger world." "Then there is a space, your space, where you create your own world, and it is your responsibility to take good care of your world."Thorough this first test, Priyakumar wants to emphasis on this point that we are totally ignorant about our surrounding. That is why. We are living disastrous life that is making our life dead. We are the composite of natural objects. When we will not remain in touch of them how we can feel happiness. How can our life to be blessed. "We all came here for a reason bigger than going to work and making money". As a person it is our duty to find out this reason and work for it. Many times in the range of Himalayas, Arjun feels the presence of someone who is calling him. When he asks chandu why he is feeling so he replies, "Thesemountains look still, sahib, but they are not. They move, they are alive, they speak, they share your soul".

In the second Test, he was asked to be in his circle and makes it better as much as he can. He remains in the circle and tries his best to make his environment better .He tries to heal the horse by wrapping its wound by his shirt and provide it grass to feel him better. After that he buried the dead stench deer baby and filled the small holes with uprooted dried leaves and flowers. In this manner, he had sorted out his environment all by himself. He was exited to feel that he can do the work. But he was fail again in this test also according to the saint, "Every person in our world has a significant role in our purpose, especially those who are a part of your journey - your wife, your children, your colleagues. People are in our lives and our path for a contribution by virtue of who they are. When people's purposes meet, then their paths align and they come together for a common purpose.

And everyone who is a part of your life is like a parallel line running alongside you and growing in their journey 
with you- your world is safe with them, and their world is safe with you." "If someone occupies your space, he or she occupies it for a reason, and that reason must serve you, him or her and the world at large. If it is your space, then it is your responsibility to know who is in your space and what role they are playing in your purpose".

In the third test "The world will change and let the world change, but don't let your state of positivity change. Let the world change, but don't let your state of certainty change to doubt because you don't like that change. Let the whole world change, but don't let your happiness change in accordance with the apparent despair the world projects onto you. If you hold on to your state of understanding and power and render that unchanged, then by the sheer stability of certainty you will change the world. When you don't change your state of power you have control over what changes or remains constant around you. The world responds to who you are."

The book also has one more important point mentioned which is based on the Law of Nature- ABUNDANCE. "It's your choice whether you want to sow seeds of goodness, happiness or the seeds of unhappiness, stress and pain. You shall reap in abundance as per the law of nature." This journey for Arjun is not a journey for pilgrimage , this is his calling-the calling to find him, his sense of duty and purpose of life and to realize the power of that spirit which is omnipresent.

\section{CONCLUSION}

In this book, Priya Kumar strongly states the condition of the current scenario where people are running blindly to collect materialistic items in the hope that it will provide them happiness but do not know that happiness come to have purpose in life. This purpose cannot be achieved individually. It requires good company, good thoughts, and collaborative effort to feel this ecstasy. Pious mind can feel divinity and natural surroundings of Himalayas, hurdle of the way and interpretation of Chandufor every incident ignite the purity and divinity in the heart of Arjuna which burns all the mess of his life and enlightened him

\section{REFERENCES}

Buell, Lawrence. The Environmental Imagination: Thoreau, Nature Writing and the

Coupe, Laurence, ed. The Green Studies Reader: From Romanticism to Ecocriticism (Routledge, 2000). Print Formation of American Culture. Cambridge, London, England: Harvard University Press, 1995

Frederick Suresh, (2012) Contemporary Contemplation on Ecoliterature, Authorpress, New Delhi.

Garrard Greg, Ecocriticism. Routledge, USA, 2004Glotfelty, Cheryll and Fromm, Harold, eds., (1996) TheEcocriticism Reader: Landmarks in Literary Ecology (University of Georgia Press). Print

Jha Shivani, (2015) Ecocritical Readings Rethinking Nature And Environment, Partridge India.

Kumar, Priya. (2016) The Calling - Unleash Your True Self. Books That Inspire 1St Edition

Mishra S.K. (2016) Ecocriticism in Children's Literature: An Analysis of AmitGarg's Two Tales.Galaxy, Vol-5, Issue 5,91-97

Mishra, Sandip Kumar. (2016). Ecocriticism: A Study of Environmental Issues in Literature. BRICS Journal of Educational Research.pp.168-170

Selvamony Z Nirmal, Nirmaldasan, Rayson K. Alex, (2012) Essays in Ecocriticism, Sarup \& Sons, New Delhi, 2007, Reprint.

Sharma, Robin S. (2006). The Monk Who Sold His Ferrari. Mumbai, Agartha road, India: Jaico Pub. House. 